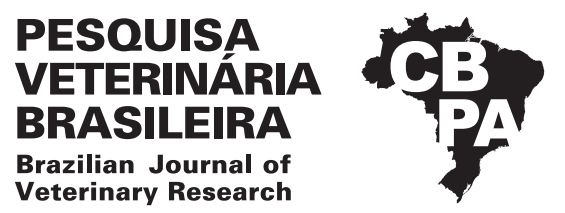

Pesq. Vet. Bras. 39(3):192-200, March 2019 DOI: 10.1590/1678-5150-PVB-5814

Original Article

ISSN 0100-736X (Print)

ISSN 1678-5150 (Online)

\title{
Causes of death and euthanasia in domestic cats in the Santa Catarina plateau (1995-2015) ${ }^{1}$
}

\author{
Jéssica A. Withoeft ${ }^{2,4}$ (D), Thierry G. Cristo ${ }^{2,4}$ (D), Giovana Biezus, \\ Leonardo S. Costa ${ }^{2,4}$, Tainah P. Dal Pont ${ }^{2,3}$, Amanda C. Freitas ${ }^{2,3}$, \\ Sandra D. Traverso ${ }^{2}$ (i) and Renata A. Casagrande ${ }^{2 *}$ (1)
}

\begin{abstract}
Withoeft J.A., Cristo T.G., Biezus G., Costa L.S., Dal Pont T.P., Freitas, A.C., Traverso S.D. \& Casagrande R.A. 2019. Causes of death and euthanasia in domestic cats in the Santa Catarina plateau (1995-2015). Pesquisa Veterinária Brasileira 39(3):192-200. Laboratório de Patologia Animal, Centro de Ciências Agroveterinárias, Universidade do Estado de Santa Catarina, Av. Luís de Camões 2090, Bairro Conta Dinheiro, Lages, SC 88520-000, Brazil. E-mail: renata.casagrande@udesc.br

Knowledge about the causes of death in felines constitutes important information to owners, veterinarians, and researchers, aiming at reducing the number of deaths in this species. In order to determine the main causes of death or euthanasia in cats in the Santa Catarina plateau, data from 1995 to 2015 available in necropsy files of the Laboratory of Animal Pathology (LAPA) of the State University of Santa Catarina (UDESC) were collected and evaluated. In that period, 1,728 cats were necropsied, mainly males $(46.12 \%)$ and adults $(50.11 \%)$. The mean ages at death for kittens, adults, and elderly were 5.07 months, 3.9 years, and 13.9 years, respectively. Of the 1,728 necropsy reports assessed, the cause of death was identified in 1,184 (68.52\%) cases. The main cause of death was associated with infectious diseases (15.8\%), with prevalence of feline infectious peritonitis $(29.76 \%)$, followed by neoplasms $(11.98 \%)$ with lymphoma (44.93\%) and leukemia (16.91\%) as the most common, and traumas (11.81\%) mainly caused by motor vehicle accidents. These results show the need for owner awareness, as well as establishment of prophylaxis and vaccination programs, aimed at reducing the number of deaths and thus increasing life expectancy in the feline population.
\end{abstract}

INDEX TERMS: Euthanasia, domestic cats, Santa Catarina, mortality, infectious diseases, neoplasm, trauma, cats, necropsy.

\begin{abstract}
RESUMO.- [Causas de morte e eutanásia em felinos domésticos no Planalto de Santa Catarina (1995-2015).] O conhecimento a respeito da causa mortis em felinos é importante para que se construa um informativo para proprietários, médicos veterinários e pesquisadores, objetivando a redução no número de mortes na espécie. Com o intuito de determinar as principais causas de morte ou eutanásia em felinos domésticos no planalto catarinense foram avaliados

\footnotetext{
${ }^{1}$ Received on September 14, 2018.

Accepted for publication on November 12, 2018.

${ }^{2}$ Laboratório de Patologia Animal, Centro de Ciências Agroveterinárias, Universidade do Estado de Santa Catarina (UDESC), Av. Luís de Camões 2090, Bairro Conta Dinheiro, Lages, SC 88520-000, Brazil. *Corresponding author: renata.casagrande@udesc.br

${ }^{3}$ Student of Veterinary Medicine, Universidade do Estado de Santa Catarina (UDESC), Av. Luís de Camões 2090, Bairro Conta Dinheiro, Lages, SC 88520-000.

${ }^{4}$ Postgraduate Program in Animal Science, Universidade do Estado de Santa Catarina (UDESC), Av. Luís de Camões 2090, Bairro Conta Dinheiro, Lages, SC 88520-000.
}

os arquivos de registro das necropsias do período de 1995 a 2015 do Laboratório de Patologia Animal da Universidade do Estado de Santa Catarina. No período, foram necropsiados 1.728 felinos, principalmente machos $(46,12 \%)$, adultos $(50,11 \%)$. A idade média para filhotes foi de 5,07 meses, enquanto para adultos foi 3,9 anos e para idosos 13,9 anos. Das 1.728 necropsias de felinos, a enfermidade que levou o animal a morte foi determinada em $1.184(68,52 \%)$. As doenças infecciosas foram a principal causa de morte $(15,8 \%)$, dentre as quais a peritonite infecciosa felina $(29,76 \%)$ foi a mais frequente; seguida das neoplasias $(11,98 \%)$, sendo o linfoma $(44,93 \%)$ e a leucemia $(16,91 \%)$, as mais comuns; e dos traumatismos $(11,81 \%)$, principalmente atropelamentos por veículos automotivos. Estes resultados refletem a necessidade da conscientização dos proprietários, bem como da instituição de programas de profilaxia e vacinação, visando a redução de mortes e o aumento na expectativa de vida para a população felina. 
TERMOS DE INDEXAČ̃̃O: Eutanásia, felinos domésticos, Santa Catarina, mortalidade, doenças infecciosas, neoplasia, traumatismos, gatos, necropsia.

\section{INTRODUCTION}

Information on the causes of death of a given species constitutes an important tool to provide epidemiological studies with data, and thus enable the planning of methods for prevention and treatment of high-prevalence diseases (Santo 2007). The preparation of a set of statistical data on the causes of death of individuals is usually based on the primary cause of death, and do not include other associated factors that contribute to the death of the animal, as in chronic diseases. For this reason, few studies addressing the comprehensive causes of mortality of a given species have been conducted, which can be justified by the difficulty in obtaining reliable data for epidemiological analysis (Fighera et al. 2008).

Pets, particularly dogs and cats, are raised according to the routine of humans, which often leads to incorporation of bad habits into their way of life, and can deprive them of their natural behavior. These inflicted influences can contribute to reduction of their life expectancy (Berzins 2000). Estimates of survival for a given animal population is informative for current and prospective owners, veterinarians, and researchers, comparing differences and similarities in mortality rates across breed or gender preferences and suggesting theories about the causes and possible evolutions of a disease (Bonnett et al. 2005).

Knowledge about mortality in felines is applicable to the understanding and correlation between associated factors and specific characteristics, such as eating and living habits, breed, gender, age, and origin. Still from the epidemiological standpoint, it suggests patterns of occurrence of certain diseases, facilitating the establishment of differential diagnoses based on clinical manifestations or complementary tests, such as laboratory and histopathological analyses. From these findings, it provides subsidies to the establishment of prophylactic measures, promoting a better quality of life and reducing the percentage of deaths due to a specific illness, such as infectious diseases (Fighera et al. 2008).

In general, studies addressing the causes of death in felines in Brazil are scarce (Trapp et al. 2010, Togni et al. 2018), as well as epidemiological data on the prevalence of conditions associated with feline death in the Santa Catarina plateau region. Therefore, this study aimed to determine the most prevalent diseases in felines that died in the aforementioned region from data obtained through a retrospective analysis of the causes of death or euthanasia in animals necropsied in the Laboratory of Animal Pathology (LAPA), at the State University of Santa Catarina (UDESC), located in the municipality of Lages, Santa Catarina state, Brazil.

\section{MATERIALS AND METHODS}

Data on cats necropsied at the LAPA/UDESC from January 1995 to December 2015 were obtained through a retrospective analysis of necropsy files. Individuals of all age groups, breeds, and genders were included in the study. Due to lack of information on the records, data such as size, weight, coat, castration, and origin of the animals were not considered. The data were organized into spreadsheets that included diagnosis and classification of the diseases. Regarding age, animals were classified into three categories according to Trapp etal. (2010): kittens ( $\leq 1$ year of age), adults ( $\geq 1$ year $<11$ years), and elderly ( $>11$ years of age).

The cause of death documented and assessed for the study corresponded to the macroscopic, as in trauma, or histopathological diagnoses. Aiming to facilitate the descriptive analysis of the data and interpretation of the results, all documented causes of death were classified as follows: degenerative diseases (including natural death); malformations; endocrine or metabolic diseases; infectious diseases, subdivided into viral, bacterial and fungal; intoxications and toxi-infections (of accidental, drug and criminal origin, in addition to disturbances caused by accumulation of endogenous toxins in the organism); neoplasms; nutritional disorders; parasitic diseases; traumas; other (diseases not included in the previously determined categories). Cases were considered inconclusive when the necropsy findings did not enable a concise diagnosis of the cause of death. Their justifications included absence of lesions or only observation of incidental lesions that did not result in death, as well as corpses in advanced state of postmortem changes, which hindered interpretation of the macro- and microscopic aspects of disease.

\section{RESULTS}

In the study period 1,728 felines were necropsied at the LAPA/UDESC. Of these, 797 (46.12\%) were males, 680 (39.35\%) were females, and 251 (14.52\%) did not have their gender informed in the reports. Regarding breed, the numbers and percentages of necropsies were as follows: 1,107 $(64,06 \%)$ crossbred (CB), 267 (15.45\%) Siamese, 130 (7.52\%) Persian, five (0.29\%) Angora, five (0.29\%) Himalayan, and four $(0.23 \%)$ Brazilian shorthair. The remainder of the cases $(210 ; 12.15 \%)$, did not have their breed informed in the necropsy reports. Table 1 shows the age group distribution according to gender.

Of the total of 1,728 records assessed, 1,184 (68.52\%) cases showed defined diagnoses of the cause of death (Table 2),

Table 1. Frequency distribution of gender and age group of cats necropsied at the LAPA/UDESC from 1995 to 2015

\begin{tabular}{|c|c|c|c|c|c|c|c|}
\hline \multirow{2}{*}{ Gender } & \multirow{2}{*}{ Age group } & \multicolumn{2}{|c|}{ Frequency } & \multicolumn{4}{|c|}{ Age (years) } \\
\hline & & $(\mathrm{N})$ & $(\%)$ & Mean & $\mathrm{SD}^{\mathrm{a}}$ & Min. ${ }^{b}$ & $\operatorname{Max}^{c}$ \\
\hline \multirow[t]{3}{*}{ Males } & Kittens* & & 19.77 & 0.46 & 0.25 & 0.04 & 0.92 \\
\hline & Adults & 454 & 73.58 & 3.6 & 2.52 & 1 & 10 \\
\hline & Elderlies & 41 & 6.65 & 14.25 & 2.87 & 11 & 24 \\
\hline \multirow[t]{3}{*}{ Females } & Kittens* & 120 & 23.12 & 0.42 & 0.24 & 0.02 & 0.92 \\
\hline & Adults & 325 & 62.62 & 4.37 & 2.92 & 1 & 10 \\
\hline & Elderlies & 74 & 14.26 & 13.5 & 2.33 & 11 & 26 \\
\hline
\end{tabular}

a Standard deviation, ${ }^{\mathrm{b}}$ minimum age, ${ }^{\mathrm{c}}$ maximum age; * All kittens aged $<1$ year. 
Table 2. Classification of diseases diagnosed in cats necropsies at the LAPA/UDESC from 1995 to 2015

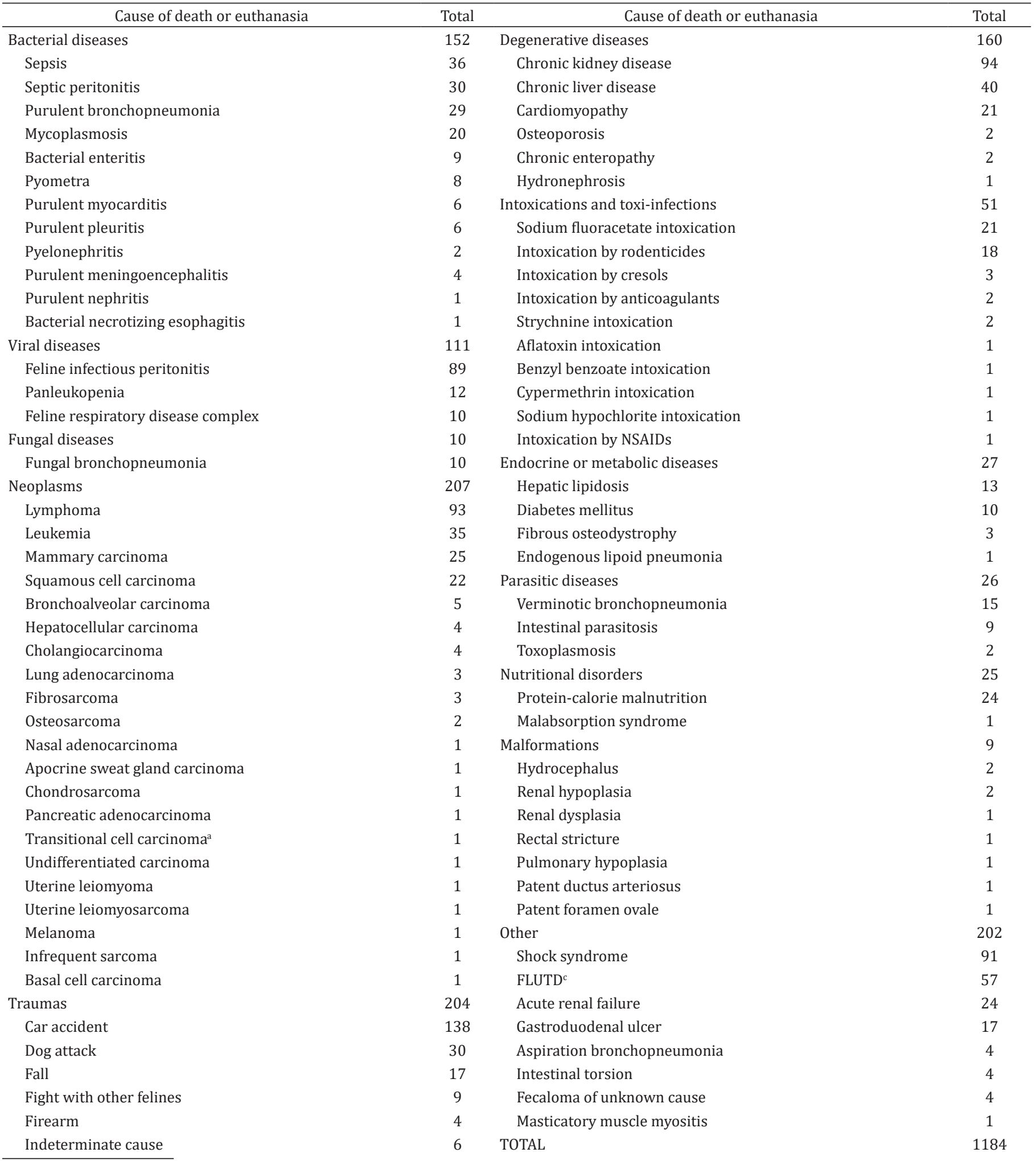

$\overline{{ }^{a}}$ Originated in the urinary bladder, ${ }^{b}$ nonsteroidal anti-inflammatory drugs, ${ }^{c}$ feline lower urinary tract disease. 
whereas 544 (31.48\%) cases showed inconclusive diagnoses, of which $454(83.45 \%)$ lacked data to confirm diagnosis, $39(7.17 \%)$ showed no micro or macroscopic changes, 30 (5.51\%) showed no diagnostic data, and 21 (3.86\%) was in advanced state of postmortem changes. Table 3 shows the classification of diseases according to age group.

Infectious diseases were the main causes of death in the cats, with prevalence of adult males $(67 / 273 ; 24.54 \%)$ over adult females $(44 / 273 ; 16.11 \%)$. Although bacterial diseases were the most frequent, feline infectious peritonitis (FIP) (Fig.1A), caused by Coronavirus, accounted for 32.6\% (89/273) of the deaths, with prevalence of adult cats $(38 / 89 ; 42.70 \%)$ aged 2.3 years on average, with $39(43.82 \%)$ males and 36 $(40.45 \%)$ females. Sepsis was the second cause of death $(36 / 273 ; 13.18 \%)$ observed in the necropsy reports assessed in this disease category, most of them caused by fetal dystocia $(12 / 36 ; 3.33 \%)$, with prevalence of adults $(20 / 36$; $55.55 \%)$. Bacterial septic peritonitis was the third most frequently observed diagnosis (Fig.1B), comprising 10.99\% (30/273) of the deaths. In this case, there was higher occurrence in females than in males, with $46.66 \%(14 / 30)$ and $43.33 \%$ $(13 / 30)$ of the deaths, respectively, with predominance of adults (mean age of 3.2 years) with a death rate of $43.33 \%$ $(13 / 30)$. As primary causes of septic peritonitis, perforated gastroduodenal ulcers were identified in $53.33 \%(16 / 30)$ of the cases; the other causes included, in all, nine cases (30\%), with postoperative wound dehiscence, rupture of the urinary bladder, puerperal metritis, pyometra, onfalitis, and liver abscess syndrome among the most significant. It was not possible to identify the main cause of peritonitis in five cats (16.66\%). Purulent bronchopneumonia was the fourth most commonly diagnosed cause of death $(29 / 273 ; 10.62 \%)$, with higher incidence in adult males (7/29;24.14\%). Mycoplasmosis caused by Mycoplasma haemofelis was detected in $7.33 \%$ $(20 / 273)$ of the cases, with prevalence of adult male cats $(11 / 20 ; 55.0 \%)$. Feline panleukopenia was responsible for $4.39 \%(12 / 273)$ of the deaths, affecting mostly female $(7 / 12$; $58.33 \%)$ and adult $(6 / 15 ; 40.0 \%)$ cats. Table 2 shows the other deaths resulting from infectious diseases.
Neoplasms were the second most frequent cause of death among the necropsy reports assessed, with prevalence of females $(93 / 207 ; 44.93 \%)$ compared with males $(91 / 207$; $43.96 \%$ ), and age group incidence as follows: adults (121/207; $58.45 \%)$, elderly $(41 / 207 ; 19.81 \%)$, and kittens $(7 / 207$; $3.38 \%$ ). Lymphoma was the most frequently diagnosed neoplasm, responsible for $44.93 \%(93 / 207)$ of the deaths, with predominance of males $(49 / 93 ; 52.69 \%)$ aged 4.4 years on average. The most affected organs, in isolation or associated with the infiltrate of neoplastic lymphocytes in more organs, were liver (49/93), kidneys (23/93), mediastinum (19/23), lymph nodes (17/93), spleen (17/93; Fig.1C), bone marrow (10/93), intestines (9/93), heart (8/93), lungs (6/93), and thymus (5/93). Leukemia (Fig.1D) followed lymphoma, accounting for $16.91 \%$ (35/207) of the deaths, with males $(19 / 35,54.28 \%)$ aged 4.4 years on average as the most affected. Mammary carcinoma was diagnosed in $12.07 \%(25 / 207)$ of the necropsied cats, with prevalence of elderly females $(23 / 25,92 \%)$ with mean age of 11.7 years. The following sites were the most affected by single or multiple metastases: lungs $(24 / 25 ; 96 \%)$, lymph nodes $(6 / 25 ; 24 \%)$, liver (5/25; $20 \%)$, kidneys (5/25; $20 \%)$, heart ( $4 / 25 ; 16 \%)$, and spleen $(4 / 25 ; 16 \%)$. Squamous cell carcinoma was a significant cause of euthanasia observed in the necropsy files evaluated, accounting for $10.63 \%$ (22/207) of the cases, with males $(10 / 22 ; 45.45 \%)$ with mean age of 7.3 years as the most affected. The neoplasms were mainly located in the nasal plane $(12 / 22,54.5 \%)$, followed by the lip commissure $(6 / 22$, $27.27 \%)$, eyelid region $(3 / 22 ; 13.63 \%)$, and ear pinna ( $3 / 22$; $13.63 \%)$. Squamous cell carcinoma metastases were found in seven cats, located in the liver (4), lungs (1), lymph nodes (1), and kidneys (1). The other neoplasms were responsible for a number of deaths $\leq 5$ each, totaling $15.46 \%(32 / 207)$ of all death caused by neoplasia (Table 2).

Deaths caused by trauma were more frequent in males $(96 / 204 ; 47.06 \%)$ than in females $(84 / 204 ; 41.18 \%)$ cats, and was most often caused by car accidents $(138 / 204 ; 67.65 \%)$, dog attacks (30/204; 14.70\%), falls (17/204; 8.33\%), fights with other felines $(9 / 204 ; 4.41 \%)$, and firearm $(4 / 204 ; 1.96 \%)$ (Fig.1E). Regarding the type of trauma, traumatic brain injury was

Table 3. Categories of diseases of cats necropsied at the LAPA/UDESC from 1995 to 2015 with their respective age group distribution

\begin{tabular}{|c|c|c|c|c|c|c|}
\hline \multirow{2}{*}{$\begin{array}{c}\text { Disease } \\
\text { classification }\end{array}$} & \multicolumn{2}{|c|}{ Frequency } & \multicolumn{4}{|c|}{ Age (years) ${ }^{\mathrm{a}}$} \\
\hline & $(\mathrm{N})$ & $(\%)$ & Mean & $\mathrm{SD}^{\mathrm{b}}$ & Min..$^{c}$ & Max. $^{d}$ \\
\hline Infectious $^{\ddagger}$ & 273 & 15.8 & 2.89 & 3.13 & 0.03 & 15 \\
\hline Neoplasms & 207 & 11.98 & 6.7 & 4.6 & 0.08 & 20 \\
\hline Traumas & 204 & 11.81 & 2.5 & 3.04 & 0.04 & 14 \\
\hline Degenerative & 160 & 9.26 & 6.5 & 5.5 & 0.16 & 24 \\
\hline Toxic* & 51 & 2.95 & 1.9 & 1.3 & 0.5 & 7 \\
\hline Nutritional & 25 & 1.45 & 1.33 & 2.3 & 0.04 & 10 \\
\hline Malformations & 9 & 0.52 & 2.1 & 4.18 & 0.04 & 13 \\
\hline Other & 202 & 11.68 & 3.27 & 3.14 & 0.05 & 19 \\
\hline Inconclusive & 544 & 31.48 & 3.98 & 4.15 & 0.008 & 26 \\
\hline
\end{tabular}

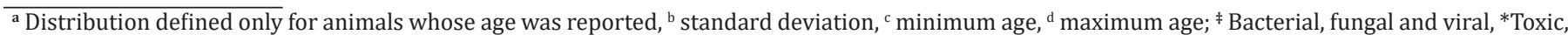
including intoxications and toxi-infections, ${ }^{\dagger}$ Metabolic, comprising endocrinologic and metabolic disorders. 
the most prevalent $(45 / 204,22.06 \%)$, followed by abdominal rupture with evisceration and thoracic trauma, with $11.27 \%$ $(23 / 204)$ of the cases each. Pelvic fractures accounted for $10.29 \%$ $(21 / 204)$ of the trauma cases, followed by fractures of pelvic limbs (19/204; 9.13\%); spleen rupture (12/204; 5.88\%), and fractures of thoracic limbs (11/204; 5.39\%). The remainder of trauma cases was responsible for a number $\leq 10$ cases each, totaling 24.51\% (50/204) of the deaths (Table 2).

Degenerative diseases affected a larger number of adults $(87 / 160 ; 54.37 \%)$ compared with those of elderly $(27 / 160$;
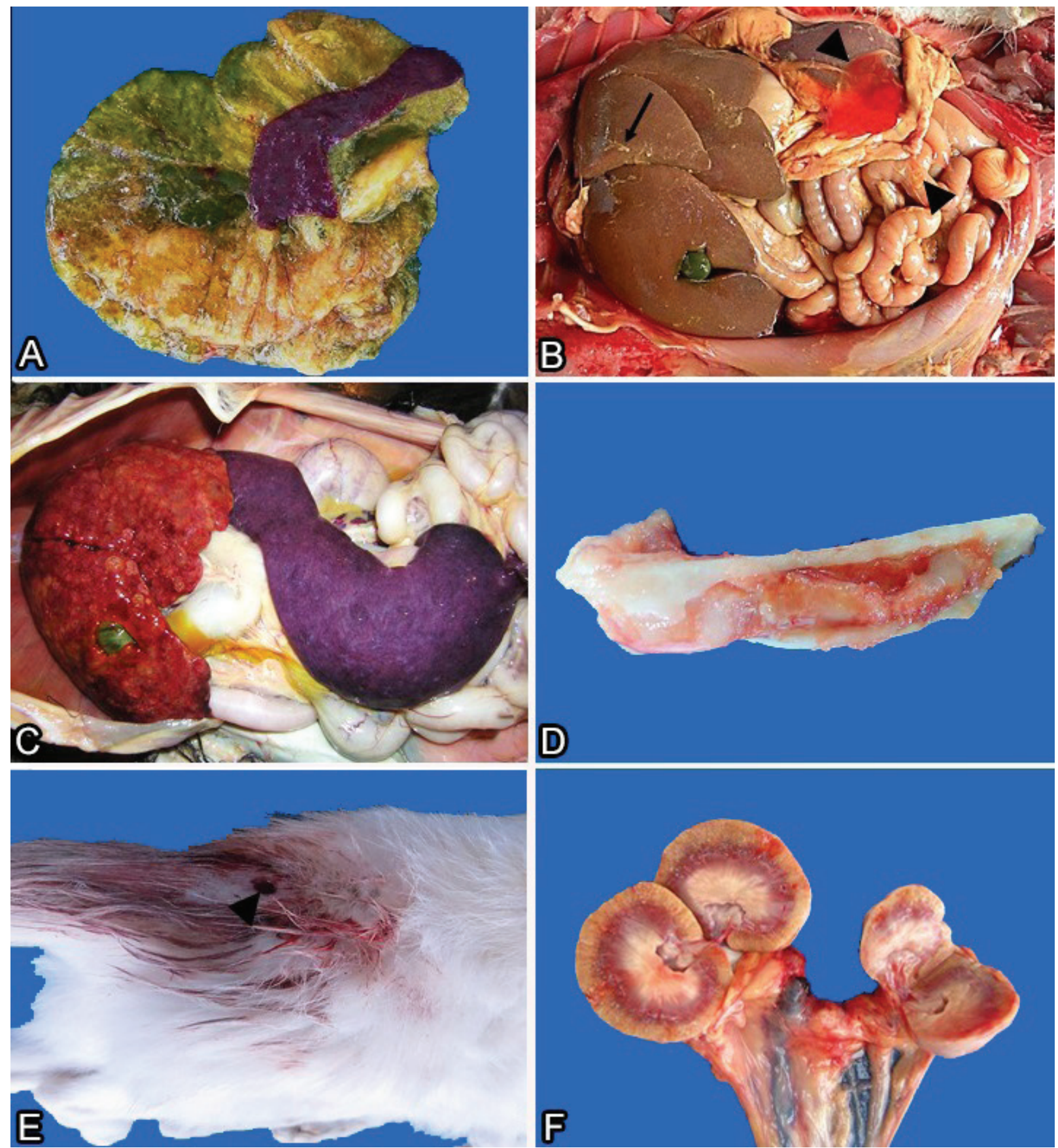

Fig.1. Causes of death and euthanasia in domestic cats in the Santa Catarina plateau. (A) Feline infectious peritonitis (FIP); spleen with an intensely irregular surface, next to diffusely swollen omentum, with multifocal fibrin bundles. (B) Bacterial peritonitis; abdominal cavity filled with bloody fluid and fibrin bundles adhered to the surface of the hepatic (thin arrow) and splenic capsules, omentum and intestinal serosa (arrow heads). (C) Lymphoma; diffuse, pronounced splenomegaly and multiple hepatic nodulations resulting from infiltration of neoplastic lymphocytes into the parenchyma. (D) Chronic lymphocytic leukemia; bone marrow with diffuse, pale, opaque parenchymal mass. (E) Injury caused by perforating instruments; perforation caused by firearm bullets (arrow head) in the sacrococcygeal region. (F) Chronic kidney disease; irregular kidney surface with whitish lines and intense retraction of the cortex in the left renal parenchyma. 
$16.87 \%)$ and kittens $(13 / 160 ; 8.12 \%)$. Chronic renal disease was most prevalent $(94 / 160 ; 58.75 \%$ ) (Fig.1F) among cats aged 6.8 years on average, followed by chronic liver disease $(40 / 160 ; 25 \%)$ in the group with mean age of 6.9 years, and cardiomyopathies $(21 / 160 ; 13.12 \%)$, with prevalence of idiopathic hypertrophic cardiomyopathy $(11 / 21 ; 52.38 \%)$, in the group with mean age of 4.3 years. There were two cases of dilated cardiomyopathy (9.5\%), and the remaining eight cases regarded congestive heart failure with no determined primary cause (38.09\%). The other degenerative diseases were responsible for $\leq 2$ deaths each, totaling $3.75 \%(6 / 160)$ of the cases (Table 2).

Among the deaths caused by intoxications or toxi-infections, sodium fluoracetate intoxication was the most prevalent with $41.17 \%(21 / 51)$ of the cases, followed by intoxication by rodenticides (18/51,35.29\%), and strychnine and anticoagulants $(4 / 51 ; 7.84 \%)$. The other informed cause intoxications accounted for $15.68 \%$ (8/51) of the deaths, including intoxications by ectoparasiticides (benzyl benzoate) and medications (nonsteroidal anti-inflammatory drugs - NSAIDs). The largest number of deaths in this category occurred in males (28/51; $54.9 \%)$; it was reported in $29.41 \%(15 / 51)$ of the females, with $50.98 \%(26 / 51)$ of the cases in adult cats.

Among the endocrine or metabolic diseases, idiopathic hepatic lipidosis was responsible for $48.15 \%(13 / 27)$ of the deaths, with predominance in females $(7 / 13 ; 53.85 \%)$ and adults $(7 / 13 ; 53.85 \%)$ aged five years on average. Diabetes mellitus was diagnosed in $37.03 \%$ (10/27) of the necropsied cats. Fibrous osteodystrophy, which was attributed to food origin in all cases, occurred in $11.11 \%$ (3/27) of the deaths. Verminotic bronchopneumonia caused by Aelurostrongylus abstrusus was the most prevalent parasitic disease, with $57.69 \%$ $(15 / 26)$ of the cases. Nutritional disorders included mainly protein-calorie malnutrition, and accounted for $96 \%(24 / 25)$ of the deaths, with higher incidence observed in kittens $(12 / 24$; $50.0 \%)$ and adults $(6 / 24 ; 25.0 \%)$. Congenital malformations predominantly affected kittens $(6 / 9 ; 66.66 \%)$, and the most frequently observed diagnoses were hydrocephalus and renal hypoplasia, responsible for two deaths each (44.44\%). Rectal stricture, pulmonary hypoplasia, patent ductus arteriosus, and patent foramen ovale were also found in the necropsy files, accounting for one case each, contributing to $55.55 \%$ (5/9) of the cases of death in this disease category.

The category "Other" comprised animals with no history but with lesions compatible with shock syndrome, including pulmonary edema and congestion, but of indeterminate cause and absence of other gross or microscopic lesions $(91 / 202$, $45.04 \%)$. Considering that feline lower urinary tract disease (FLUTD) is a multifactorial disorder, it was the second most reported condition in this category $(57 / 202 ; 28.21 \%)$. FLUTD was predominant in males (48/57; 84.21\%) and adult (35/57; $61.40 \%$ ) cats with mean age of 4.5 years. Acute renal failure, mainly due to nephrotoxicity, was responsible for $11.88 \%$ $(24 / 202)$ of the deaths. Gastroduodenal ulcer accounted for $7.42 \%(15 / 202)$ of the cases of death were more common in males $(9 / 15 ; 60 \%)$ and adult $(46.66 \%)$ felines. The other causes of death in this category corresponded to less than five cases each $(15 / 202 ; 7.42 \%$ (Table 2$)$.

\section{DISCUSSION}

Of the 1,728 felines necropsied at the LAPA/UDESC, males were prevalent (46.12\%), data compatible with those reported in the literature (Lacheretz et al. 2002); however, the percentage of animals that did not have the gender informed (14.52\%) should be considered. In the adult age group, the proportion of necropsied males was also higher (56.96\%) compared with that of females (47.79\%), and one of the justifications for this difference is the greater environmental exposure of males, which leave in search of females for mating, exposing themselves to a larger number of stressors and pathogens, whereas females have periods of isolation during the puerperium (Berzins 2000). The age range including the reproductive period also explains the predominance of necropsied adults in relation to kittens and elderly. There are no studies addressing the correlation between breed and prevalence of deaths in felines; however, it is known that crossbred cats are predominant, which was confirmed by the larger number of necropsies in these animals observed in the present study (64.06\%).

Infectious diseases were the most common cause of feline death in this study (15.8\%). Studies conducted with dogs have also shown infectious diseases as the main cause of death (Bentubo et al. 2007, Fighera et al. 2008), but these data differed from those of previous studies on cats, in which deaths caused by trauma (Togni et al. 2018) or complications involving idiopathic urinary tract diseases were the most diagnosed (Trapp et al. 2010). Wilkie et al. (2015) assessed 252 cases of death in felines and concluded that heart disease was the most common cause of death (55\%), with prevalence of hypertrophic cardiomyopathy (68\%).

Adult males were the feline population most affected by infectious diseases (24.54\%), with feline infectious peritonitis (FIP) as the most prevalent condition. This is in agreement with findings of previous studies, which demonstrated that a larger number of males, aged 3 months to 3 years (Oliveira et al. 2003), unneutered (Rohrbach et al. 2001) cats were affected by Coronavirus. This finding is again justified by the susceptibility of unneutered males to infectious diseases due to the search for in-estrus females and greater access to external environments, which culminate in greater contact with felines of unknown origin, facilitating the dissemination of infectious agents. Sepsis has been presented as a common condition in felines (12.04\%), with pneumonia, endocarditis, pyelonephritis, pyometra, septic pancreatitis, pyothorax, peritonitis, and meningitis among its main prerequisites (Declue etal. 2011). Sepsis is defined as the systemic inflammatory reaction secondary to the action of bacteria, viruses, fungi, or parasites (Bone et al. 1992). In this study, sepsis was mainly associated with dystocia with fetal death. The occurrence of infectious diseases, particularly viral diseases in general, is also associated with the low participation in vaccination programs, fundamental in their control, which are eventually neglected by owners due mostly to socioeconomic aspects (Bentubo et al. 2007).

Cats infected with the feline leukemia virus (FeLV) are predisposed to a wide variety of diseases, especially infectious diseases, considering that there is intense immunosuppression, with a larger number of diseases diagnosed in animals with FeLV. Also, neoplasms of lymphoid origin have been largely observed in these animals (Hagiwara et al. 1997). These lymphoproliferative disorders can be classified according to 
the affected sites, the morphological aspect of the neoplastic cells, and to the cytochemical and immunological markers (Rojko et al. 1989, Gabor et al. 1998). It is known that prevalence of infection with FeLV in the Santa Catarina plateau is $22.26 \%$, and that factors such as aggressiveness contribute to seropositivity, especially in males (Biezus 2017), similarly to what was found in the present study, in which cases of lymphoma (44.93\%) were more prevalent in male felines (52.69\%). Lymphoma is classified as follows: multicentric - characterized by widespread involvement of structures such as the liver, spleen, lymph nodes and, in some cases, bones; mediastinal - characterized by lymphadenopathy in the mediastinum, with focal, multifocal or diffuse neoplastic infiltration in the gastrointestinal tract structures, with or without intra-abdominal lymphadenopathies; extranodal - which can affect any organ or tissue atypically, such as the central nervous system, eyeball, epidermis, kidneys, etc. (Couto 2000). In previous studies, involvement of organs in the abdominal cavity was more common; however, despite this intra-abdominal involvement, there has been predominance in structures of the gastrointestinal tract and not in the liver or spleen, characterizing lymphoma as nutritional and not as multicentric (Gabor et al. 1998), which differs from the location in the liver predominantly found in this study. The intestines, in turn, were classified only as the seventh organ most affected by the neoplastic infiltrate. Leukemia was less frequently observed than lymphoma, and also prevalent in males (54.28\%).

In the category of neoplasms, mammary carcinoma $(12.07 \%)$ was predominant in females (92\%) with mean age of 11.7 years. It is known that carcinoma is the most common mammary neoplasia, affecting adult-to-elderly females. Quite often, the use of synthetic progestogens for suppression of estrus contributes to the emergence of benign or malignant neoplasms of the mammary gland (Amorim et al. 2004), and there is need for awareness-raising programs regarding the harm caused by this practice. In the present study, it was not possible to establish the number of females that had mammary carcinoma as a result of this practice. Squamous cell carcinoma was the fourth most prevalent neoplasm in felines (10.63\%), especially in those with white coat and prolonged exposure to the ultraviolet rays of sunlight, which cause crusty and hyperemic lesions that evolve in neoplasia, and are thus locally aggressive, affecting felines with mean age of 7.3 years. This finding differs from data reported in previous studies, in which the approximate age for the occurrence of this disease was 11 years and 4 months (Ruslander et al. 1997).

Deaths resulting from trauma were only the third most frequent, in disagreement with the data obtained by Trapp et al. (2010), who classified this category as the most prevalent cause of death in felines, but in agreement with the identification of deaths caused by car accidents $(67.65 \%)$ as the most common. Males were the most affected by trauma (47.06\%), which may be associated with their frequent access of a larger proportion of unneutered stray male cats. A study conducted by Bentubo et al. (2007) with dogs verified that traumas were also the third most frequent cause of death. Traumatic brain injury was the most commonly described $(22.06 \%)$, differing from data of previous studies, which have observed traumas in the appendicular skeleton as the most frequent (Vidane et al. 2014). Nevertheless, it should be considered that this previous study addressess trauma in live animals, because traumatic brain injury is often fatal without veterinary assistance. In addition, pets show reduced body mass and, as a consequence, large contact surface for impact, considering that an animal with traumatic brain injury is also a polytraumatized individual (Siqueira et al. 2013).

Chronic kidney disease was the most prevalent in the category of degenerative diseases (58.75\%), corroborating the results of a previous study that assessed the causes of death in domestic felines aged $>9$ years, in which this disease was predominant, accounting for 42 deaths out of 121 animals evaluated (Manteigas et al. 2013). However, in the present study, degenerative diseases accounted for a larger number of adults (54.37\%) compared with that of elderly $(16.87 \%)$, although the mean age of these adult individuals (6.8 years) should be considered, closer to that of elderly. Due to lack of information in the necropsy files, it was not possible to distinguish accidental from criminal intoxications. In cases in which it was possible to identify the active principle that determined the intoxication, there was predominance of sodium fluoracetate $(41.17 \%)$, a powerful rodenticide. Clinical findings associated with sodium fluoracetate poisoning include vomiting, diarrhea, hypothermia, tachypnea, hyperexcitability, mydriasis, vocalisation, and convulsive episodes, and may result in death when the condition is not reversed (Collicchio-Zuanaze 2002). Again, the most affected population comprised males (54.9\%) and the adult age group (50.98\%), because toxic agents are included within the risk factors for unneutered male cats that have access to the streets, especially in the case of criminal poisoning.

Feline hepatic lipidosis, the most common endocrine or metabolic disease (48.15\%), is associated with accumulation of triglycerides in the hepatocytes, precluding adequate metabolism. Among the predisposing factors for its occurrence, it worth highlighting the exacerbated mobilization of fatty acids from the adipose tissue to the liver as a result of anorexia, mainly in obese animals, with greater availability of lipids for gluconeogenesis, because glucose levels in the bloodstream are reduced in anorexia (Dimski \& Taboada 1995). Quite often, the primary cause of anorexia is not established, considering not only pathological, but also behavioral changes. One of the most common predisposing conditions in diabetes mellitus $(37.03 \%)$ in felines is obesity. It is associated with poorly formulated diets with excessive caloric intake, leading to reversible insulin resistance and tissue resistance to glucose (Veiga 2005).

There are no epidemiological studies determining the frequency of protein-caloric malnutrition, the main one among those of nutritional origin (96\%), as a cause of death. It is believed to be associated with abandonment of kittens, the predominant age group in this case $(50.0 \%)$, once again evidencing the importance of the castration process in small animals, avoiding the proliferation of stray animals. Congenital anomalies are poorly described in felines, and there is difficulty in determining the prevalence of hydrocephalus and renal hypoplasia in this species due to lack of epidemiological data describing them. Regarding congenital heart anomalies, a study conducted in Sweden by Tidholm et al. (2015) demonstrated that these anomalies represent $0.2 \%$ of the total feline patients, with interventricular septal defect as the most documented, corresponding to $50 \%$ of the cases. 
The literature presents no data on the prevalence of shock syndrome in felines, but it is known that it is a multifactorial event associated with deficient energy production by the cells due to inadequate blood circulation, with consequent deficient oxygen supply to the tissues, leading to cell degeneration and necrosis, organ failure, and death, if not reversed in time (Shaffran 2004). The necropsy findings include mainly pulmonary congestion and edema; however, they are nonspecific findings, and thus prevent the etiology of shock from being determined when there is no history of or concomitant lesions.

Feline lower urinary tract disease (FLUTD) was quite prevalent (32.20\%) in this study. It is a multifactorial disorder often associated with the ingestion of industrialized dry diets, which favor the formation of calculi, as well as of diets rich in minerals such as magnesium, phosphates and calcium, which favor the appearance of urolithiasis, in addition to low water intake, characterized by the peculiar habits of some animals. Sedentary lifestyle and obesity may also be considered predisposing factors for FLUTD (Rosa \& Quitzan 2011). FLUTD is prevalent in male (84.21\%) and adult (61.40\%) cats, and is associated with the anatomical conformation of the urethra of the males, which favors the installation of obstructive processes, mainly by formation of urethral plugs (Reche Junior et al. 1998). Discontinuation of urinary flow may also lead to postrenal azotemia, evolving to renal failure and death (Finco \& Barsanti 1984). In acute renal failure, the third most prevalent disease in this category, decreased renal function due to factors such as nephrotoxicity is observed, as well as to deficits in the excretion of metabolites such as urea and creatinine, which acutely accumulate in the bloodstream and lead to a condition of uremia that can evolve to death (Rufato et al. 2011).

\section{CONCLUSIONS}

Infectious diseases were the main causes of death or euthanasia in domestic cats necropsied at the LAPA/UDESC in the Santa Catarina plateau region, with feline infectious peritonitis (FIP) as the most prevalent disease in adult males, followed by neoplasms, especially lymphoma and leukemia, which were also more prevalent in adult males.

Both causes of death may be associated with the way of life of these animals, exposed to a greater number of pathogens compared with females, mainly those of viral origin, reinforcing the need for vaccination and castration programs in felines.

Conflict of interest statement.- The authors have no competing interests.

\section{REFERENCES}

Amorim F.V., Souza H.J.M. \& Ferreira A.M.R. 2004. Avaliação clínico-cirúrgica de nódulos mamários felinos através da citologia e histopatologia. Braz. J. Vet. Res. Anim. Sci. 41:204-205.

Bentubo H.D.L., Tomaz M.A., Bondan E.F. \& Lallo M.A. 2007. Expectativa de vida e causas de morte em cães na área metropolitana de São Paulo (Brasil). Ciência Rural 37(4):1021-1026. <http://dx.doi.org/10.1590/ S0103-84782007000400016>

Berzins M.A.V.D.S. 2000. Velhos, cães e gatos: interpretação de uma relação. Masters Thesis, Faculdade de Saúde Pública, Universidade de São Paulo. 162p.

Biezus G. 2017. Infecção pelos vírus da leucemia felina (FeLV) e imunodeficiência (FIV) em gatos do planalto de Santa Catarina: prevalência, fatores associados, alterações clínicas e hematológicas. Masters Thesis, Centro de Ciências Agroveterinárias, Universidade de Santa Catarina, Lages. 91p.

Bonnett B.N., Egenvall A., Hedhammar A. \& Olson P. 2005. Mortality in over 350,000 insured swedish dogs from 1995-2000: I. Breed-, gender-, ageand cause-specific rates. Acta Vet. Scand. 46(3):105-120. <http://dx.doi. org/10.1186/1751-0147-46-105><PMid:16261924>

Bone R.C., Balk R.A., Cerra F.B., Dellinger R.P., Fein A.M., Knaus W.A., Schein R. \& Sibbald W.J. 1992. Definitions for sepsis and organ failure and guidelines for the use of innovative therapies in sepsis. Chest 101(6):1644-1655. $<$ PMid:1303622>

Collicchio-Zuanaze R.C. 2002. Intoxicação por Fluoroacetato de sódio: avaliações clínica, hemogasométrica, eletrocardiográfica e da eficácia do gluconato de cálcio e succinato de sódio como protocolo terapêutico. Masters Thesis, Faculdade de Medicina Veterinária e Zootecnia, Universidade Estadual Paulista, Botucatu. 133p.

Couto C.G. 2000. Advances in the treatment of the cat with lymphoma in practice. J. Feline Med. Surg. 2(2):95-100. <http://dx.doi.org/10.1053/ jfms.2000.0079><PMid:11716600>

Declue A.E., Delgado C., Chang C. \& Sharp C.R. 2011. Clinical and immunologic assessment of sepsis and the systemic inflammatory response syndrome in cats. J. Am. Vet. Med. Assoc. 238(7):890-897. <http://dx.doi.org/10.2460/ javma.238.7.890 > <Mid:21453177>

Dimski D.S. \& Taboada J. 1995. Feline idiopathic hepatic lipidosis. Anim. Pract. 25(2):357-373.<PMid:7785168>

Fighera R.A., Souza T.M., Silva M.C., Brum J.S., Graça D.L., Kommers G.D., Irigoyen L.F. \& Barros C.S.L. 2008. Causas de morte e razões para eutanásia de cães da mesorregião do centro ocidental Rio-Grandense (1965-2004). Pesq. Vet. Bras. 28(4):223-230. <http://dx.doi.org/10.1590/S0100736X2008000400005>

Finco D.R. \& Barsanti J.A. 1984. Diet-induced feline urethral obstruction. Vet. Clin. N. Am., Small Anim. Pract. 14(3):529-536. <http://dx.doi.org/10.1016/ S0195-5616(84)50059-X><PMid:6610977>

Gabor L.J., Malik R. \& Canfield P.J. 1998. Clinical and anatomical features of lymphosarcoma in 118 cats. Aust. Vet. J. 76(11):725-732. <http://dx.doi. org/10.1111/j.1751-0813.1998.tb12300.x><PMid:9862061>

Hagiwara M.K., Reche Júnior A. \& Lucas S.R.R. 1997. Estudo clínico da infecção de felinos pelo vírus da leucemia felina em São Paulo. Revta Bras. Ciênc. Vet. 4:35-38.

Lacheretz A., Moreau D. \& Cathelain H. 2002. Causes of death and life expectancy in carnivorous pets (I). Rev. Méd. Vét. 153:819-822.

Manteigas F., Godinho A., Almeida P. \& Grande C. 2013. Causas de mortalidade em gatos com mais de nove anos: estudo retrospectivo de cem casos. Revta Lusófona Ciênc. Med. Vet. 6:47-57.

Oliveira F.N., Raffi M.B., Souza T.M. \& Barros C.S.L. 2003. Peritonite infecciosa felina: 13 casos. Ciência Rural 33(5):905-911. <http://dx.doi.org/10.1590/ S0103-84782003000500018>

Reche Junior A., Hagiwara M.K. \& Mamizuka E. 1998. Estudo clínico da doença do trato urinário inferior em gatos domésticos de São Paulo. Braz. J. Vet. Res. Anim. Sci. 35(2):69-74. <http://dx.doi.org/10.1590/S141395961998000200004>

Rojko J.L., Kociba G.J., Abkowitz J.L., Hamilton K.L., Hardy Junior W.D., Ihle J.N. \& O'Brien S.J. 1989. Feline lymphomas: immunological and cytochemical characterization. Cancer Res. 49(2):345-351.<PMid:2535958>

Rosa V.M. \& Quitzan J.G. 2011. Avaliação restrospectiva das variáveis etiológicas e clínicas envolvidas na doença do trato urinário inferior dos felinos (DTUIF). Cesumar 13:103-110.

Rohrbach B.W., Legendre A.M., Baldwin C.A., Lein D.H., Reed W.M. \& Wilson R.B. 2001. Epidemiology of feline infectious peritonitis among cats examined at veterinary medical teaching hospitals. J. Am., Vet. Med. Assoc. 
218(7):1111-1115. <http://dx.doi.org/10.2460/javma.2001.218.1111> <PMid:11318361>

Rufato F.H.F., Rezende-Lago N.C.M. \& De Marchi P.G.F. 2011. Insuficiência renal em cães e gatos. Revta Eletrôn. Interdisciplinar 2:167-173.

Ruslander D., Kaser-Hotz B. \& Sardinas J.C. 1997. Cutaneous squamous cell carcinoma in cats. Compend. Contin. Educ. Pract. Vet. 19(10):1119-1129.

Santo A.H. 2007. Potencial epidemiológico da utilização das causas múltiplas de morte por meio de suas menções nas declarações de óbito, Brasil, 2003. Revta Panam. Salud Públ. 22:178-186.

Shaffran N. 2004. Shock overview: cardiogenic and non-cardiogenic shock syndromes. Proceedings X International Veterinary Emergency and Critical Care Symposium, San Diego, CA.

Siqueira E.G.M.S., Rahal S.C., De Araújo F.A.P. \& Agostinho F.S. 2013. Trauma cranioencefálico em pequenos animais. Vet. Zootec. 20:112-123.

Tidholm A., Ljungvall I., Michal J., Haggstrom J. \& Hoglund K. 2015. Congenital heart defects in cats: a retrospective study of 162 cats (1996-2013). J. Vet. Cardiol.17(Suppl.1):215-219. <http://dx.doi.org/10.1016/j.jvc.2014.09.004> $<$ PMid:26776580>
Togni M., Curtis A., Vargas D.P., Kommers G.D., Irigoyen L.F. \& Fighera R.A. 2018. Causas de morte e razões para eutanásia em gatos na Região Central do Rio Grande do Sul (1964-2013). Pesq. Vet. Bras. 38(4):741-750. <http:// dx.doi.org/10.1590/1678-5150-pvb-5075>

Trapp S.M., Iacuzio A.I., Barca Junior F.A., Kemper B., Silva L.C., Okano W., Tanaka N., Grecco F., Cunha Filho L. \& Sterza F. 2010. Causas de óbito e razões para eutanásia em uma população hospitalar de cães e gatos. Braz. J. Vet. Res. Anim. Sci. 47(5):395-402. <http://dx.doi.org/10.11606/ issn.1678-4456.bjvras.2010.26821>

Veiga A. 2005. Obesidade e diabetes mellitus em pequenos animais. Anais II Simpósio de Patologia Clínica Veterinária da Região Sul do Brasil, Porto Alegre, RS, p.82-91.

Vidane A.S., Elias M.Z.J., Cardoso J.M.M., Come J.A.S.S., Harun M. \& Ambrósio C.E. 2014. Incidência de fraturas em cães e gatos da cidade de Maputo (Moçambique) no período de 1998-2008. Ciênc. Anim. Bras. 15(4):490494. <http://dx.doi.org/10.1590/1089-6891v15i424279>

Wilkie L.J., Smith K. \& Luis Fuentes V. 2015. Cardiac pathology findings in 252 cats presented for necropsy: a comparison of cats with unexpected death versus other deaths. J. Vet. Cardiol. 17(Suppl.1):329-340. <http:// dx.doi.org/10.1016/j.jvc.2015.09.006><PMid:26776590> 